\title{
PENGOLAHAN MOTIF MENGGUNAKAN TEKNIK ESCHER DENGAN INSPIRASI TENUN IKAT SUMBA PADA BUSANA READY-TO-WEAR
}

\author{
Jeremi Samuel ${ }^{1}$ \\ (Telkom University, samuel.jeremi@gmail.com, samueljeremi@student.telkomuniversity.ac.id, 0895810483900) \\ Morinta Rosandini² \\ (Telkom University, morinta.rosandini@gmail.com, morintarosandini@telkomuniversity.ac.id, 082116610768)
}

\begin{abstract}
Moving from the potencial of processing textile pattern with tessellation composititon using non-geometry elements. The technique called Escher's technique which is used with inspiration from oramental variation of Sumba's hinggi ikat weaving because it is using non-geometry elements too. The purpose of this research is for creating new variant of Ready-to-wear clothing. Mixed method applied in this research which is quantitative method by doing the experiment mathematically and qualitative method by doing observation about both the used of tessellation composition and the characteristic of Sumba's hinggi ikat weaving and literature study of Escher's technique. Next is the experiment of processing textile pattern by using Escher's technique with the inspiration of ornamental variation of Sumba's hinggi ikat weaving. The experiment results applied using surface design's technique which is digital printing and embroidery accent and developed become menswear Ready-to-wear. The used of Escher's technique for processing motif still can be developed with various inspirations.
\end{abstract}

Keywords: Escher's technique, motif, Sumba's hinggi ikat weaving, tessellation, ready-to-wear

\section{ABSTRAK}

Berangkat dari potensi pengolahan motif dengan komposisi tessellation menggunakan komponen nongeometri. Teknik yang digunakan disebut teknik Escher dengan inspirasi ragam hias tenun ikat hinggi Sumba karena tenun ikat hinggi Sumba memiliki ragam hias dengan unsur penyusun bidang nongeometri.Tujuan penelitian ini adalah untuk menciptakan variasi baru pada busana Readyto-wear. Metode campuran digunakan pada peneltian ini, yaitu metode kuantitatif dengan melakukan penghitungan matematis pada saat proses eksperimen dan kualitatif dengan melakukan observasi penggunaan pattern dengan komposisi tessellation juga karakter tenun ikat hinggi Sumba dan studi pustaka mengenai teknik Escher. Dilanjutkan dengan proses eksperimen pengolahan motif secara digital menggunakan teknik Escher dengan inspirasi ragam hias tenun ikat hinggi Sumba. Hasil eksperimen diaplikasikan dengan teknik surface design, yaitu digital printing dan aksen bordir yang kemudian dikembangkan menjadi produk busana Ready-to-wear untuk pria. Penggunaan teknik Escher pada pengolahan motif dapat dikembangkan lagi dengan berbagai inspirasi.

Kata kunci: motif, tessellation, teknik Escher, tenun ikat hinggi Sumba, ready-to-wear. 


\section{PENDAHULUAN}

Motif adalah unsur pembentuk pattern yang dikomposisikan sedemikian rupa menjadi satu kesatuan yang dapat direpetisi (Steed \& Stevenson, 2012). Pengaplikasian pattern pada tekstil terus ada dari masa ke masa dengan sumber inspirasi terbesar pembuatan pattern berasal dari alam, seperti yang dikatakan Soetsu Yanagi, "An age without good pattern is an age that doesn't look at nature carefully" ( Steed et al., 2012, p.123). Tidak terkecuali pada zaman sekarang, pengaplikasian pattern pada busana juga banyak ditemukan pada koleksi Spring / Summer 2019, seperti motif floral koleksi Alexander McQueen, motif plaid koleksi Natasha Zinko, dan motif animal prints koleksi Roberto Cavalli (Adivi, 2019). Indonesia Trend Forecasting juga memproyeksikan trend penggunaan pattern ini pada trend forecast 2019/2020, Singularity, khususnya pada subtrend Svarga yang memiliki ciri khas tabrak corak tetapi tetap memperhatikan keseimbangan (Indonesia Trend Forecasting, 2018).

Banyak metode repetisi motif pada pembuatan pattern, salah satunya adalah teknik tessellation. Tessellation adalah proses pembuatan bidang dua dimensi dengan menggunakan unsur geometri yang direpetisi tanpa celah dan tumpang tindih (Deger, 2012). Teknik tessellation pada pembuatan pattern busana masih jarang digunakan, adapun berdasarkan observasi online, beberapa brand Indonesia yang sudah mengaplikasikan teknik tessellation pada pattern busana mereka, seperti brand Jajaka X Ivan Gunawan pada koleksinya tahun 2018 yang bergaya chic dan playfull, brand Lalake by Mucha pada koleksinya tahun 2019, Raya, dengan unsur geometri belah ketupat dan segi enam, dan brand XY pada koleksi tahun 2019, Infinitum, yang menggunakan unsur geometri belah ketupat. Selain itu, berdasarkan observasi lapangan pada salah satu mal di Bandung, didapatkan bahwa beberapa fast fashion brand seperti Zara, Pull\&Bear dan Stradivarius menggunakan pattern busana klasik dengan teknik tessellation, yaitu Houndstooth pada beberapa artikel produk mereka.

Namun, penggunaan teknik tessellation pada pattern busana masih bersifat monoton menggunakan bidang geometri, sedangkan teknik tessellation dapat digunakan juga pada bidang nongeometri, yaitu dengan menggunakan teknik Escher. M.C. Escher merupakan seorang desainer grafis yang menggunakan ilmu matematika dalam pembuatan karya-karyanya. Teknik tessellation yang diperkenalkan Escher, atau biasa disebut teknik Escher, terinspirasi dari susunan ubin yang indah dan rumit pada arsitektur di Alhambra, Spanyol. Namun, unsur pembentuk pattern hanya sebatas bentuk geometri karena larangan kaum Muslim untuk menggunakan objek hidup, sehingga Escher mencoba membuat tessellation menggunakan objek hidup seperti burung, ikan, dan kuda. Salah satu karya Escher yang menggunakan pengembangan teknik tessellation adalah The Horseman dengan unsur penyusunnya adalah pria yang sedang menunggangi kuda (Taschen, 2009).

Bentuk nongeometri biasa ditemukan pada ragam hias kain tradisional Indonesia, salah satunya adalah tenun ikat yang berasal dari Sumba, Nusa Tenggara Timur. Karakter yang khas dari tenun ikat Sumba, khususnya tenun ikat Hinggi, adalah ragam hias yang bervariasi dan didominasi bentuk nongeormetri seperti kuda, ayam, rusa dan naga, komposisi motif yang simetris dan mirror, serta penggunaan pewarna alami seperti coklat kemerahan dari akar mengkudu dan proses tenun yang masih tradisional menggunakan gedogan (Kartiwa, 2007). Kemiripan karakter ragam hias tenun ikat Sumba dan teknik Escher yang sama-sama mengolah bentuk 
non-geometri dan memiliki unsur matematis merupakan potensi yang dapat dikembangkan melalui penggabungan dua hal tersebut. Bentuk nongeormetri pada ragam hias tenun ikat Sumba yang bervariasi menjadi potensi lain untuk dijadikan inspirasi dalam mengolah motif dengan menggunakan teknik Escher, sehingga, dari beberapa potensi tersebut dapat dilakukan pengolahan motif yang terinspirasi dari ragam hias tenun ikat hinggi Sumba menggunakan teknik Escher untuk diaplikasikan pada busana Ready-to-wear.

Tujuan dari penelitian ini adalah untuk menciptakan variasi motif bidang nongeometri dengan komposisi tessellation menggunakan teknik Escher, mengaplikasikan teknik Escher dengan menggunakan inspirasi ragam hias tenun ikat hinggi Sumba dan menciptakan busana Ready-to-wear dengan aplikasi motif yang diolah menggunakan teknik Escher.

Jadi, penelitian ini berangkat dari penggunaan motif dengan komposisi tessellation yang monoton menggunakan bidang geometri pada busana, sehingga dilakukan inovasi menggunakan bidang nongeometri yang terinspirasi dari ragam hias tenun ikat hinggi Sumba dengan teknik Escher untuk menciptakan variasi pattern baru pada busana Ready-to-wear.

\section{METODE}

Metode yang digunakan pada penelitian ini adalah metode gabungan, yaitu secara kualitatif dan kuantitatif. Metode kuantitatif digunakan karena dalam pengolahan motif menggunakan tenik Escher bersifat matematis sehingga perlu dilakukan beberapa penghitungan dalam pembuatan motif tersebut. Metode kualitatif digunakan karena penelitian ini berfokus pada ekplorasi teknik yang digunakan. Adapun metode pengumpulan data yang digunakan yaitu sebagai berikut :

1. Studi Pustaka
Membaca beberapa sumber literatur seperti buku, jurnal dan artikel yang terkait dengan topik penelitian, seperti :

a. Jurnal An Application of Mathematical Tessellation Method In Interior Designing oleh Deger bersaudara tahun 2012 mengenai tessellation.

b. Buku M. C. Escher: The Graphic Work oleh TASCHEN tahun 2009 yang menjelaskan mengenai karya - karya Escher.

c. Buku Tenun Ikat : Ragam Kain Tradisional Indonesia oleh Suwati Kartiwa tahun 2007 yang menjelaskan mengenai tenun ikat Sumba.

\section{Observasi}

Observasi dilakukan dengan dua cara yaitu secara online dengan mengamati media sosial maupun website brand - brand lokal yang mengaplikasikan motif yang dikomposisikan secara tessellation pada produk mereka seperti brand Jajaka X Ivan Gunawan pada koleksinya tahun 2018, brand Lalake by Mucha pada koleksinya tahun 2019 dan brand XY pada koleksi tahun 2019. Observasi langsung juga dilakukan dengan mengunjungi mal 23 Pascal di Bandung dan didapati adanya penggunaan teknik tessellation yang diaplikasikan pada motif produk brand - brand fast fashion seperti ZARA, Pull\&Bear berupa pattern dengan komposisi tessellation klasik yang disebut dengan houndstooth.

\section{Eksperimen}

Mencoba mengaplikasikan teknik Escher yang terdiri atas empat cara, yaitu translation, reflection, rotation, dan glide reflection dengan menggunakan inspirasi ragam hias tenun ikat Sumba seperti ayam, kuda, rusa, dan naga secara digital menggunakan aplikasi Corel Draw. 


\section{HASIL DAN PEMBAHASAN}

\section{a. Teknik Escher}

Teknik Escher merupakan teknik yang ditemukan oleh Maurits Cornelis Escher (18981972) yaitu seorang desainer grafis yang menggunakan ilmu matematika dalam pembuatan karya-karyanya. Tessellation adalah proses pembuatan bidang dua dimensi dengan menggunakan unsur geometri yang direpetisi tanpa celah dan tumpang tindih (Deger, 2012). Teknik tessellation yang diperkenalkan Escher terinspirasi dari susunan ubin yang kompleks dan indah saat perjalanannya ke Alhambra di Spanyol. Namun, unsurnya hanya sebatas bentuk geometri karena larangan kaum Muslim untuk menggunakan objek hidup sehingga Escher mencoba teknik tessellation dengan menggunakan objek hidup. Salah satu karya Escher yang menggunakan teknik tessellation adalah The Horseman dengan unsur utama pria yang sedang menunggangi kuda. (Taschen, 2009)

Escher menggunakan 4 metode dalam pembuatan tessellation, yaitu :

\section{Translation}

Translation atau translasi dilakukan dengan cara memindahkan objek repetisi dengan arah dan jarak yang sama. Hasil repetisi yang diberikan akan bersifat searah. Penggunaan teknik translation pada karya Escher dapat dilihat pada gambar 3.

\section{Reflection}

Reflection atau refleksi dilakukan dengan cara membalik objek repetisi pada satu poros baik secara vertikal atau horizontal. Hasil repetisi yang diberikan akan memberikan efek mirror. Penggunaan teknik reflection pada karya Escher dapat dilihat pada gambar 4.

\section{Rotation}

Rotation atau rotasi dilakukan dengan cara memutar objek repetisi pada satu poros.
Besar derajat pemutaran objek bergantung pada bidang geometri dasar yang digunakan, seperti jika bidang geometri dasar berupa belah ketupat atau persegi berarti objek direpetisi dengan cara diputar dengan kelipatan $90^{\circ}$. Hasil repetisi yang diberikan akan memberikan efek radial atau menyebar. Penggunaan teknik rotation pada karya Escher dapat dilihat pada gambar 5 .

\section{Glide reflection}

Glide reflection dilakukan dengan cara menggabungkan metode reflection dan translation. Metode ini menghasilkan efek yang mirip dengan metode reflection, yaitu memberikan efek mirror tetapi dengan penggeseran posisi. Penggunaan teknik glide reflection pada karya Escher dapat dilihat pada gambar 6 (Deger, 2012).

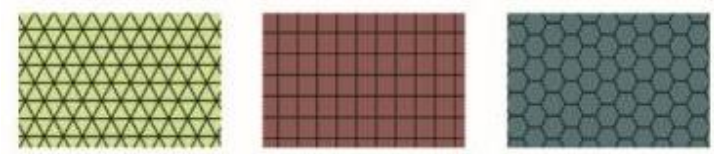

Gambar 1. Beberapa Bentuk UmumTessellation. (Sumber: Deger, 2012)

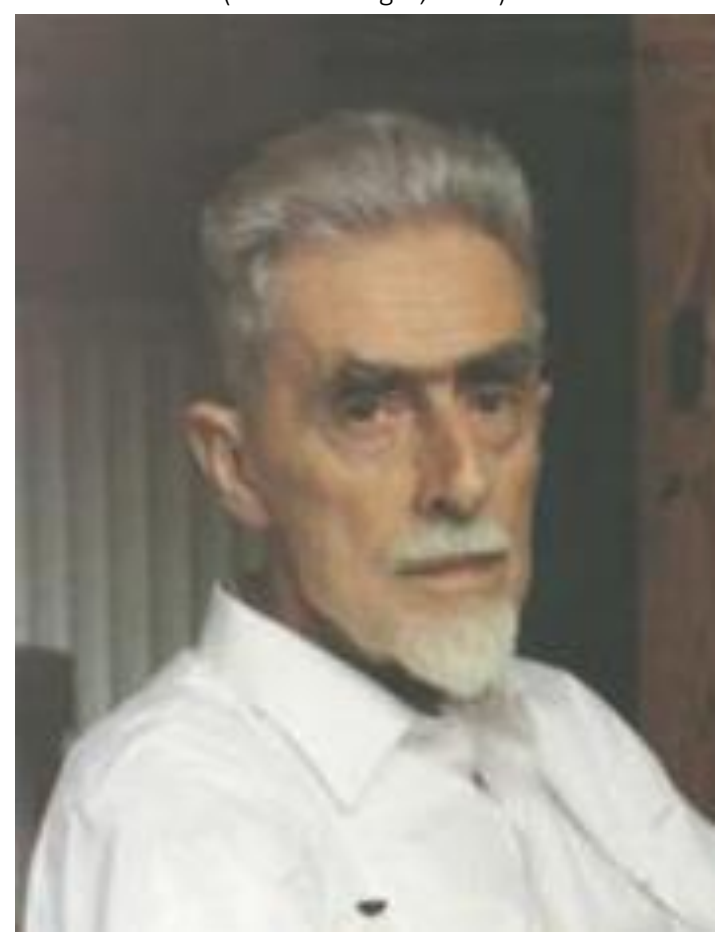

Gambar 2. Maurits Cornelis Escher (Sumber: Taschen, 2009) 


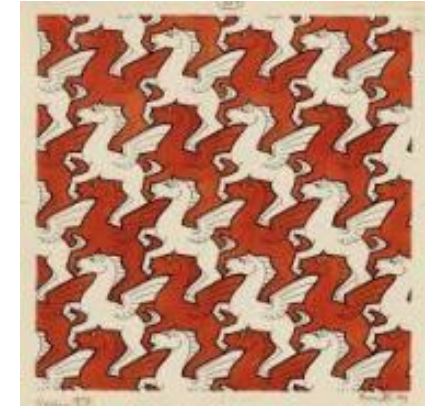

Gambar 3. Karya Escher dengan Metode Translation (Sumber: Taschen, 2009)

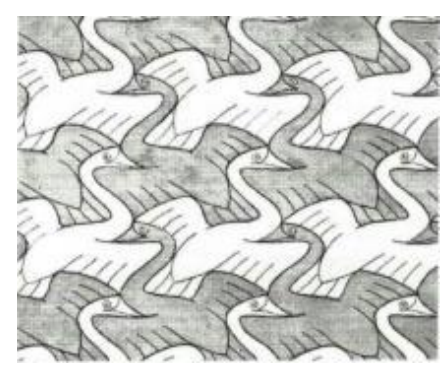

Gambar 4. Karya Escher dengan Metode Reflection (Sumber: Taschen, 2009)

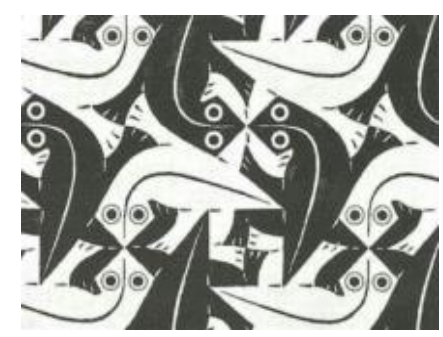

Gambar 5. Karya Escher dengan Metode Rotation (Sumber: Taschen, 2009)

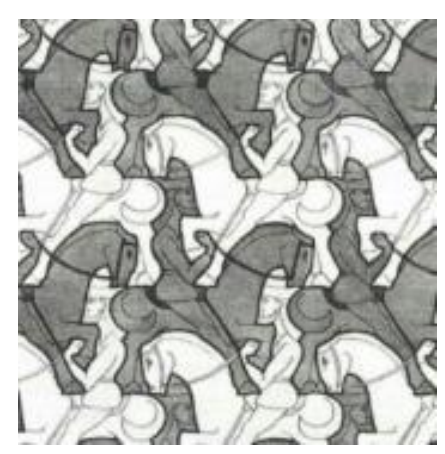

Gambar 6. Karya Escher dengan Metode Glide Reflection (Sumber: Taschen, 2009)

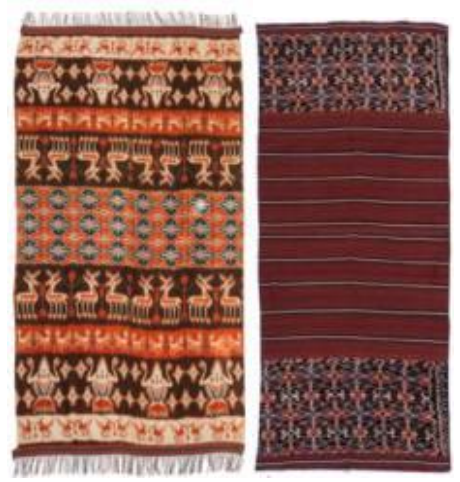

Gambar 8. Tenun Ikat Hinggi (Kiri) dan Tenun Ikat Lau (Kanan). (Sumber: Katalog Yayasan Sekar Kawung, 2017)

\section{b. Tenun Ikat Sumba}

Sumba merupakan salah satu pulau di Kepulauan Nusa Tenggara Timur. Jenis tenun Sumba yang paling terkenal adalah hinggi dan lau. Hinggi adalah kain panjang berukuran 2 meter bagi laki - laki dewasa, sedangkan lau adalah sejenis kain tenun ikat yang diberi teknik songket lungsi tambahan. Tenun ikat hinggi dipilih karena didominasi ragam hias nongeomerti, sedangkan tenun ikat lau didominasi garis.

Ragam hias tenun ikat Sumba terinspirasi dari lingkungan masyarakat Sumba sendiri yang kemudian distilasi menjadi ragam hias. Stilasi merupakan perubahan bentuk objek yang ada di alam menjadi bentuk artistik atau dengan penggayaan tertentu (Nizam, $2019,134)$. Penggayaan ragam hias tenun ikat Sumba menggunakan sistem Ruang Waktu Datar (RWD) yang memiliki cerita yang disebut bahasa rupa. Dalam sistem RWD, bahasa rupa disusun oleh unsur wimba (image) dan tata ungkapan ( seperti grammar pada bahasa kata). Wimba dibagi menjadi dua bagian, yaitu isi wimba dan cara wimba. Isi wimba adalah objek yang digambar, sedangkan cara wimba adalah bagaimana cara objek tersebut digambar. Tata ungkapan adalah cara menyusun wimba dan cara wimba, sehingga menjadi satu kesatuan untuk membuat cerita pada sebuah gambar. (Rosandini \& Kireina, 2020) 
Ragam hias tenun Sumba berupa bidang geometri dan nongeormetri. Motif geometri adalah motif yang dibentuk oleh bidang matematis, seperti segiempat, segilima, dan lingkaran, sedangkan motif nongeometri adalah motif yang dibentuk dari bidang bebas seperti dari inspirasi flora dan fauna (Kusumo, Irawani, Poerwosedjati, 2013). Ragam hias dalam tenun ikat hinggi Sumba ada yang lahir dari kepercayaan masyarakat, seperti pohon tengkorak, dari alam sekitar biasanya berupa hewan, seperti hewan laut (kuda laut, ikan, udang cumi), hewan hutan (rusa, burung, ular), dan hewan ternak (kuda dan ayam) dan ragam hias yang lahir dari budaya luar, seperti motif patola ratu dan bourag dari india, motif kerawang dari Portugis, motif bendera tiga warna, mahkota, perisai dan singa dari Belanda juga naga dari Cina (Kartiwa 2007). Ragam hias yang menjadi fokus penelitian ini berupa ayam jantan dan kuda karena kedua ragam hias tersebut sering muncul dalam tenun ikat hinggi Sumba, mudah dikenali, bentuknya tidak begitu rumit dan filosofinya yang erat dengan kejantanan. Ragam hias kuda melambangkan keberanian, kesatuan, kewibawaan dan sifat satria. Kuda dijadikan motif pada tenun ikat Sumba karena kuda sangat erat kaitannya dengan kehidupan masyarakat Sumba sebagai alat transportasi, alat tukar menukar, dan status. Kuda menjadi sumber kekayaan dan simbol status bagi pemiliknya dimana semakin banyak kuda yang dimiliki berarti semakin tinggi status sosial di masyarakat Sumba.

Ragam hias ayam digunakan pada tenun ikat Sumba karena hewan ini sering digunakan dalam upacara magis untuk mendapat ramalan seseorang. Upacara dilakukan oleh seorang tokoh adat yang disebut marapu untuk berkomunikasi dengan nenek moyang. Karena itu ayam memiliki makna kepemimpinan dan kesatuan. Motif ayam biasanya berupa figur ayam jantan dengan ciri khas jenggernya. (Kartiwa, 2007).

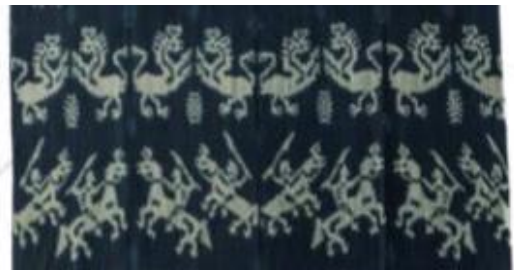

Gambar 9. Ragam Hias Kuda pada Tenun Ikat Hinggi (Sumber: Katalog Yayasan Sekar Kawung, 2017)

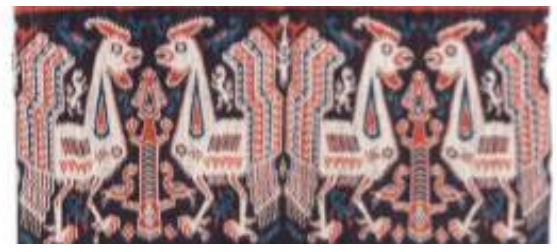

Gambar 10. Ragam Hias Ayam pada Tenun Ikat Hinggi (Sumber: Katalog Yayasan Sekar Kawung, 2017)

\section{c. Eksplorasi Awal I}

Eksplorasi awal dilakukan dengan tujuan untuk mengenal metode - metode yang ada pada teknik Escher, sehingga dilakukan uji coba metode yang terdiri dari translation, reflection, rotation, dan glide reflection dengan menggunakan objek -objek yang terdapat pada ragam hias tenun ikat hinggi Sumba. Setelah motif berhasil membentuk komposisi tessellation, motif kemudian diberi warna dan detail. Penggunaan unsur tekstur maya (invented texture) dengan cara membuat susunan bidang geometri persegi pada proses pewarnaan dan pemberian detail yang bertujuan untuk mencontoh inspirasi tekstur nyata (actual texture) pada tenun ikat Sumba karena adanya titik perpotongan benang lungsi dan pakan yang ditenun.Eksplorasi awal yang sudah dilakukan dapat dilihat pada tabel 1.

\section{d. Eksplorasi Awal II}

Pada ekplorasi lanjutan, eksplorasi dibuat lebih spesifik sesuai dengan sumber inspirasi. Pemilihan ragam hias dipersempit sebatas ayam dan kuda karena ragam hias tersebut yang paling sering muncul pada tenun 
ikat hinggi Sumba juga filosofinya yang sesuai dengan konsep. Penggunaan warna juga difokuskan pada warna-warna dasar tenun ikat hinggi Sumba, seperti merah kecoklatan dan biru beserta. Eksplorasi lanjutan dapat dilihat pada tabel 2.

\section{e. Eksplorasi Lanjutan}

Eksplorasi lanjutan bertujuan untuk menyesuaikan hasil eksplorasi awal II berdasarkan konsep yang dibuat pada penelitian ini, yaitu IKAT. Eksplorasi dilakukan dengan cara mengubah warna dan perubahan sedikit detail menjadi beberapa pilihan yang sesuai dengan konsep. Ekplorasi lanjutan yang dipilih adalah eksplorasi yang terinspirasi dari ragam hias tenun ikat hinggi Sumba berupa ayam dan kuda dengan teknik Escher translation, reflection, rotation, dan glide reflection masing - masing satu buah. Pemilihan ragam hias ayam dan kuda dikarenakan filosofi kedua ragam hias tersebut yang menggambarkan kejantanan seorang pria. Eksplorasi lanjutan dapat dilihat pada tabel 3.

No. Inspirasi Langkah
Rranslation inspirasi buaya
Ragam hias yang ditentukan untuk dijadikan sumber inspirasi adalah buaya.
Bentuk geometri dasar dibuat berupa bidang persegi panjang mengikuti
keseluruhan bentuk inspirasi. Sisi bagian kanan persegi panjang dipotong
membentuk kepala dan kaki depan lalu ditranslasi ke sisi kiri. Sisi bawah
persegi panjang dipotong membentuk kaki lalu ditranslasi ke sisi atas setengah
langkah membentuk ekor. Motif dengan siluet buaya yang sudah terbentuk
dilakukan percobaan repetisi sebelum diberi warna. Motif kemudian diberi
warna dasar mengikuti inspirasi warna tenun ikat Sumba yaitu biru muda,
merah kecoklatan, dan biru tua kemudian diberi detail seperti mata, mulut,
detail kaki, dan detail sisik buaya yang terinspirasi dari ragam hias tenun ikat
hinggi Sumba yang menggunakan prinsip kontras pada warna. Motif dibuat
menjadi tiga variasi warna yang berbeda sehingga bentuk motif terlihat jelas
setelah dikomposisikan.

Translation inspirasi udang 

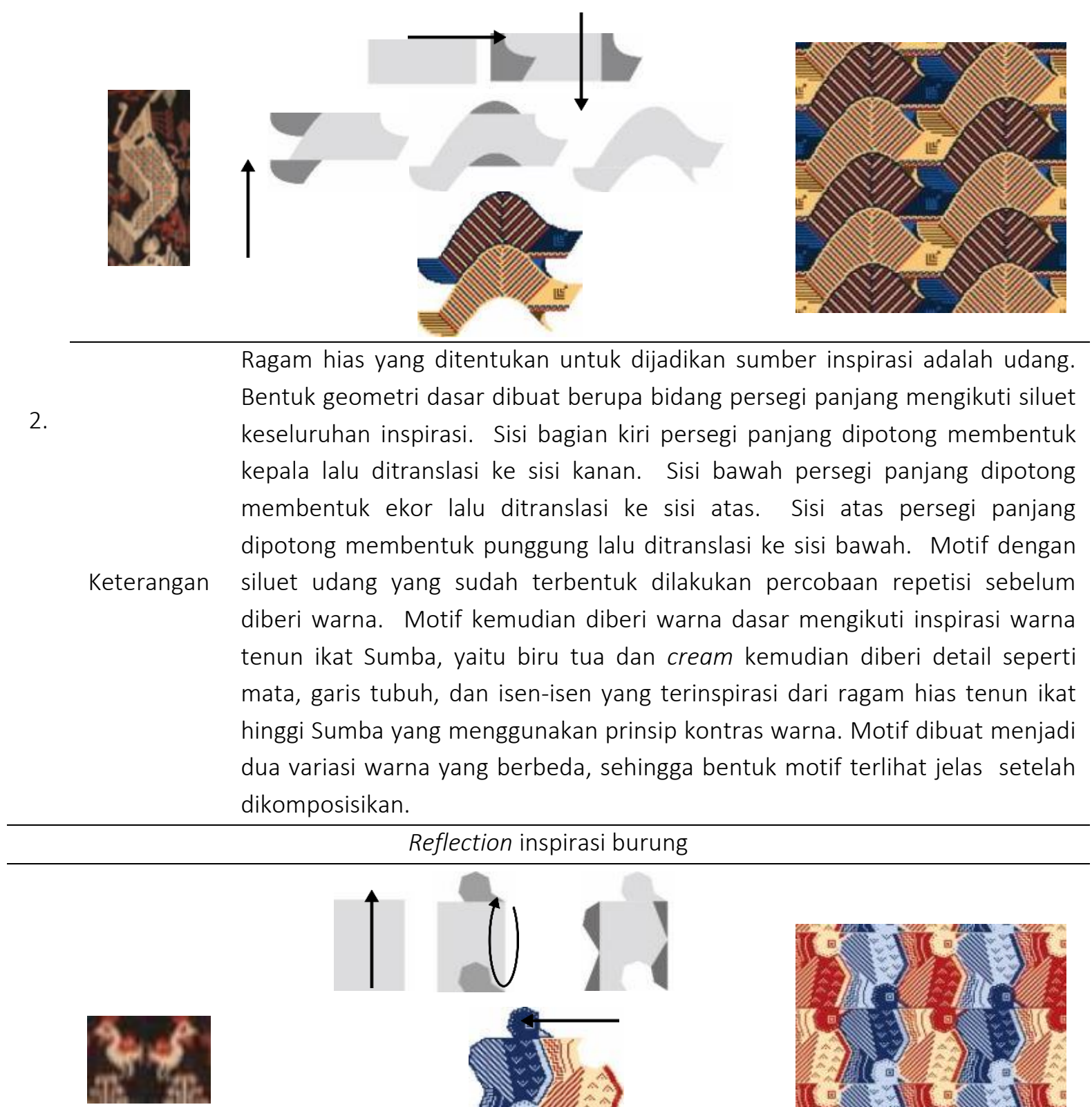

3.
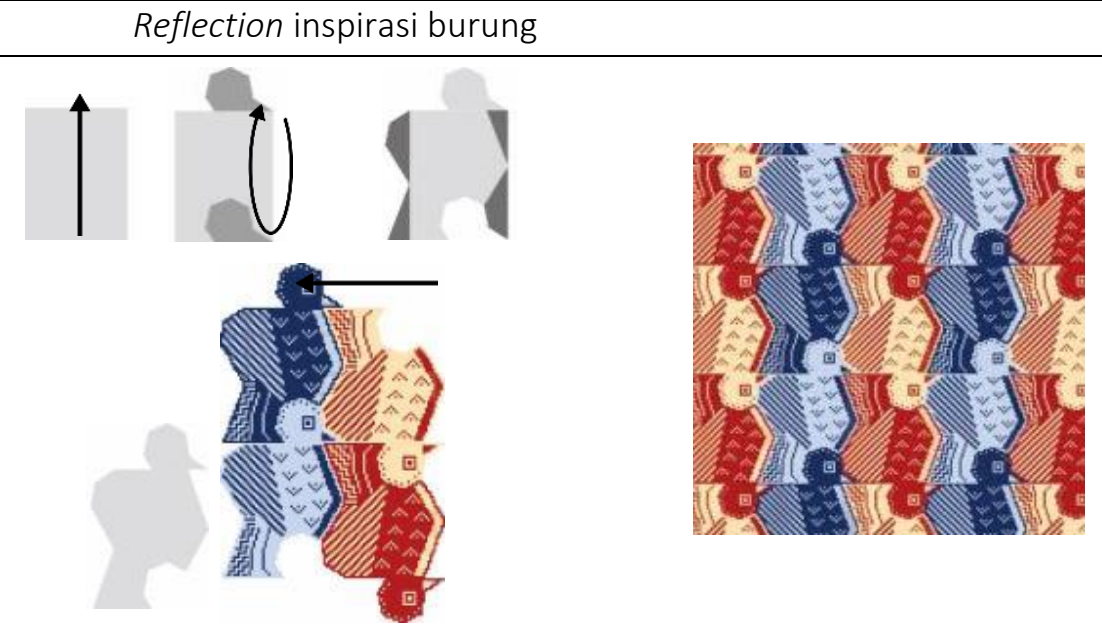

Keterangan

Ragam hias yang ditentukan untuk dijadikan sumber inspirasi adalah ayam. Bentuk geometri dasar dibuat berupa bidang persegi panjang mengikuti siluet keseluruhan inspirasi. Sisi bagian bawah persegi panjang dipotong membentuk kepala lalu ditranslasi ke sisi atas. Sisi kanan persegi panjang dipotong membentuk dada lalu direfleksi vertikal ke sisi kiri. Motif dengan siluet ayam yang sudah terbentuk dilakukan percobaan repetisi sebelum diberi warna. Motif kemudian diberi warna dasar mengikuti inspirasi warna tenun ikat Sumba yaitu biru tua, biru muda, cream, dan merah kemudian diberi detail seperti mata, paruh, dan isen-isen yang terinspirasi dari ragam hias tenun ikat hinggi Sumba yang menggunakan prinsip kontras warna. Motif dibuat menjadi 
4 variasi warna yang berbeda sehingga bentuk motif terlihat jelas setelah dikomposisikan.

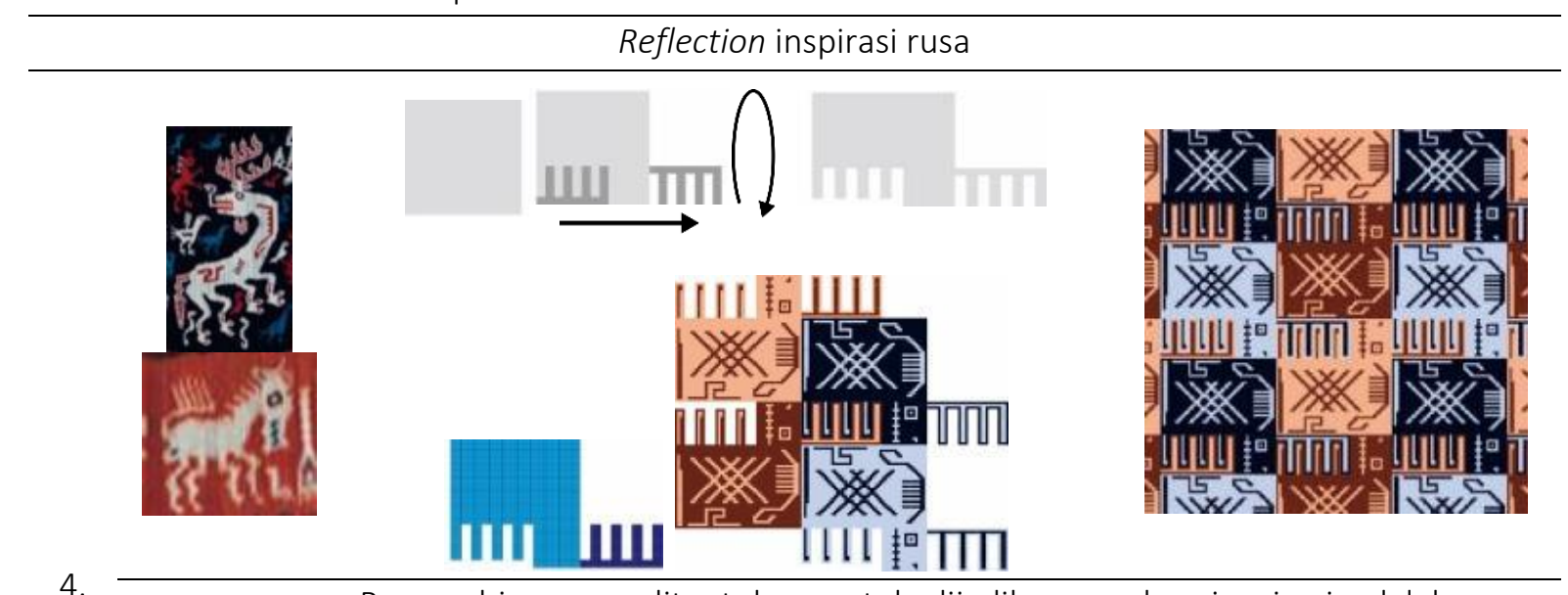

4.

Keterangan

Ragam hias yang ditentukan untuk dijadikan sumber inspirasi adalah rusa. Bentuk geometri dasar dibuat berupa bidang persegi. Sisi bagian kiri persegi dipotong membentuk kaki lalu direfleksi vertikal ke sisi kanan membentuk tanduk. Motif dengan siluet rusa yang sudah terbentuk dilakukan percobaan repetisi sebelum diberi warna. Motif kemudian diberi warna dasar mengikuti inspirasi warna tenun ikat Sumba, yaitu cream, coklat tua, biru tua, dan biru muda kemudian diberi detail seperti mata, mulut, dan isen-isen yang terinspirasi dari ragam hias tenun ikat hinggi Sumba yang menggunakan prinsip kontras warna. Motif dibuat menjadi empat variasi warna yang berbeda, sehingga bentuk motif terlihat jelas setelah dikomposisikan

\section{Rotation inspirasi ikan}

5.
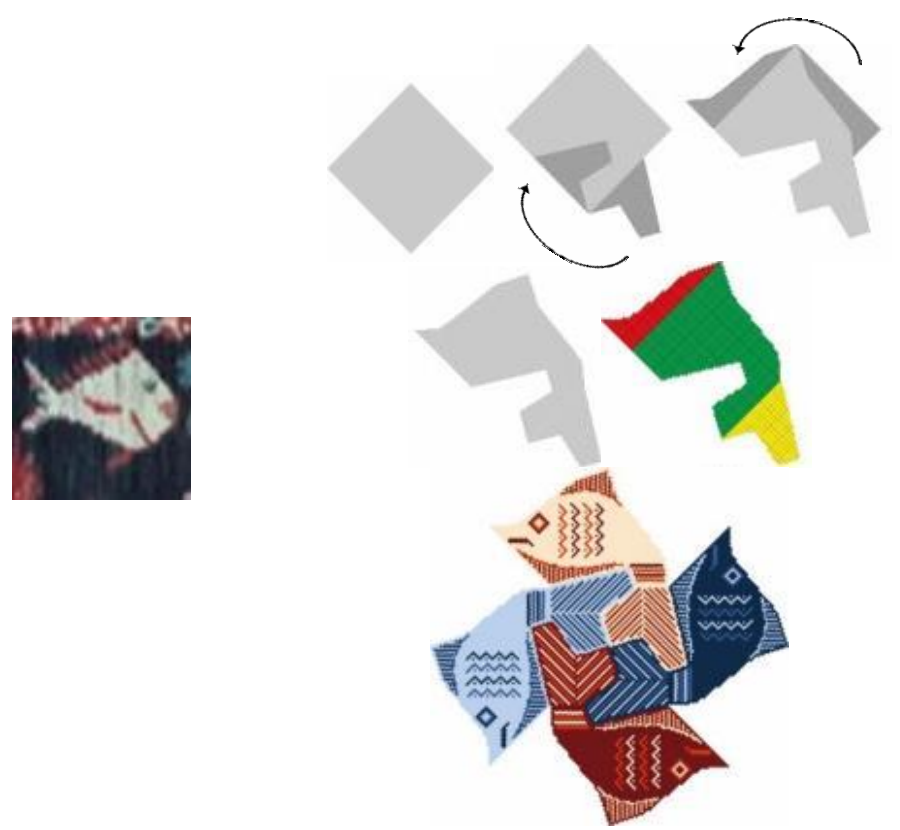

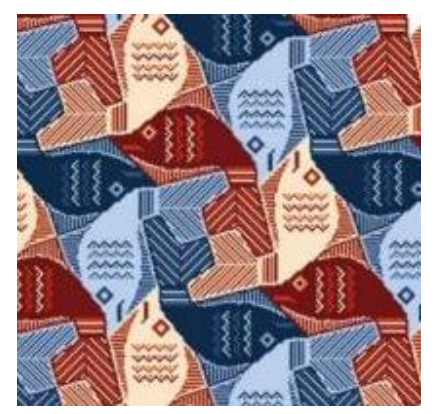

Ragam hias yang ditentukan untuk dijadikan sumber inspirasi adalah ikan.

Keterangan

Bentuk geometri dasar dibuat berupa bidang belah ketupat. Sisi kiri bawah belah ketupat dipotong membentuk ekor lalu dirotasi ke sisi bawah kanan $90^{\circ}$ karena masing - masing sudut belah ketupat membentuk sudut $90^{\circ}$. Sisi kanan 
atas belah ketupat dipotong membentuk sirip lalu dirotasi ke sisi kiri atas $90^{\circ}$ membentuk kepala karena masing-masing sudut belah ketupat membentuk sudut $90^{\circ}$. Motif dengan siluet ikan yang sudah terbentuk dilakukan percobaan repetisi sebelum diberi warna. Motif kemudian diberi warna dasar mengikuti inspirasi warna tenun ikat Sumba, yaitu cream, coklat tua, biru tua, dan biru muda kemudian diberi detail seperti mata, mulut, sisik, dan isenisen yang terinspirasi dari ragam hias tenun ikat hinggi Sumba yang menggunakan prinsip kontras warna. Motif dibuat menjadi empat variasi warna yang berbeda, sehingga bentuk motif terlihat jelas setelah dikomposisikan.

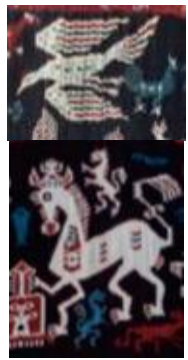

Glide reflection inspirasi burung dan kuda

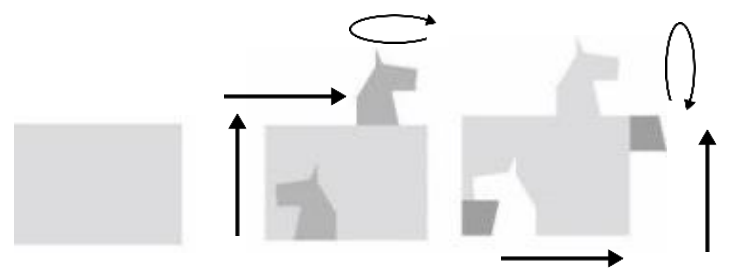

6.
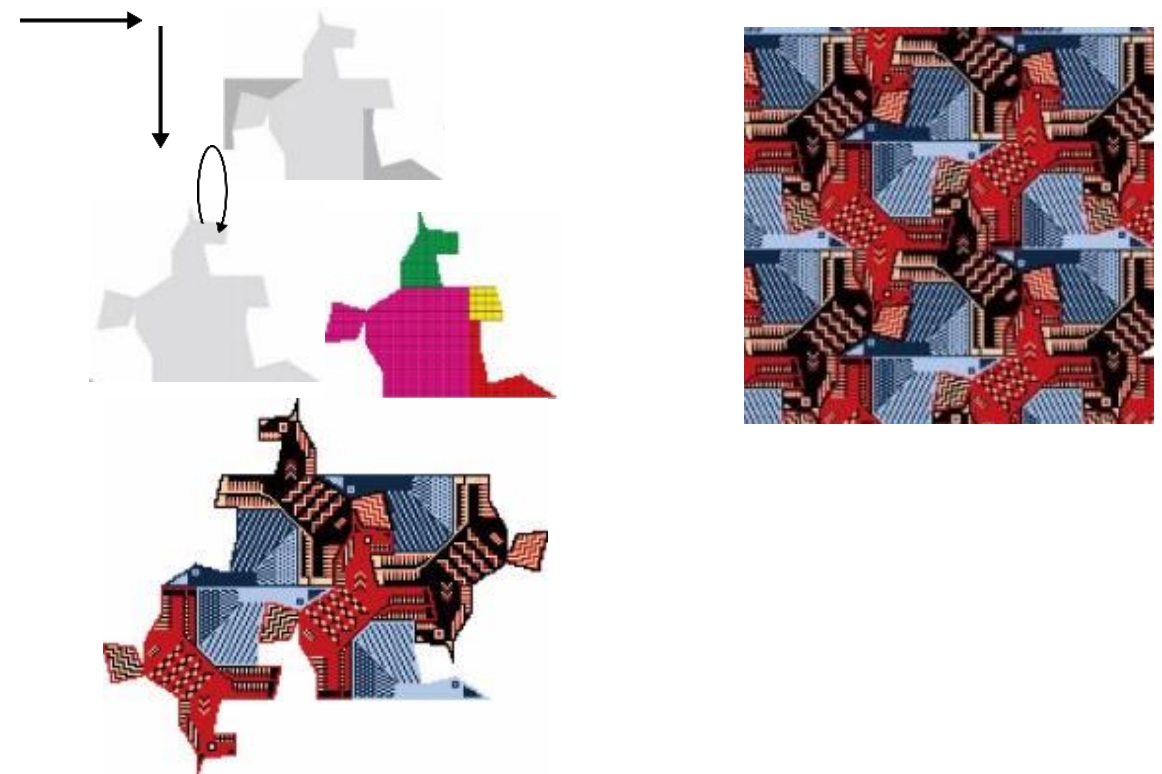

Ragam hias yang ditentukan untuk dijadikan sumber inspirasi adalah kuda dan burung. Bentuk geometri dasar dibuat berupa bidang persegi panjang. Sisi bagian bawah persegi panjang dipotong membentuk kepala kuda lalu direfleksi horizontal ke sisi atas dan ditranslasi ke kanan. Sisi kiri persegi panjang dipotong membentuk persegi lalu direfleksi vertikal ke sisi kanan lalu ditranslasi ke atas membentuk kaki. Sisi kiri persegi panjang dipotong membentuk ekor lalu direfleksi vertikal ke sisi kanan lalu ditranslasi ke bawah membentuk kepala burung. Motif dengan siluet gabungan kuda dan burung yang sudah terbentuk dilakukan percobaan repetisi sebelum diberi warna. Motif kemudian diberi warna dasar mengikuti inspirasi warna tenun ikat Sumba, yaitu hitam dan merah untuk kuda dan biru tua dan biru muda untuk burung kemudian diberi detail seperti mata, mulut, dan isen-isen yang 
terinspirasi dari ragam hias tenun ikat hinggi Sumba yang menggunakan prinsip kontras warna. Motif dibuat menjadi dua variasi warna yang berbeda, sehingga bentuk motif terlihat jelas setelah dikomposisikan.

Tabel 1. Ekplorasi Awal I.

(Sumber : Dokumentasi Penulis, 2020)

\begin{tabular}{lcc}
\hline No, Inspirasi & Langkah & Hasil \\
\hline & Translation inspirasi ayam & \\
\hline
\end{tabular}
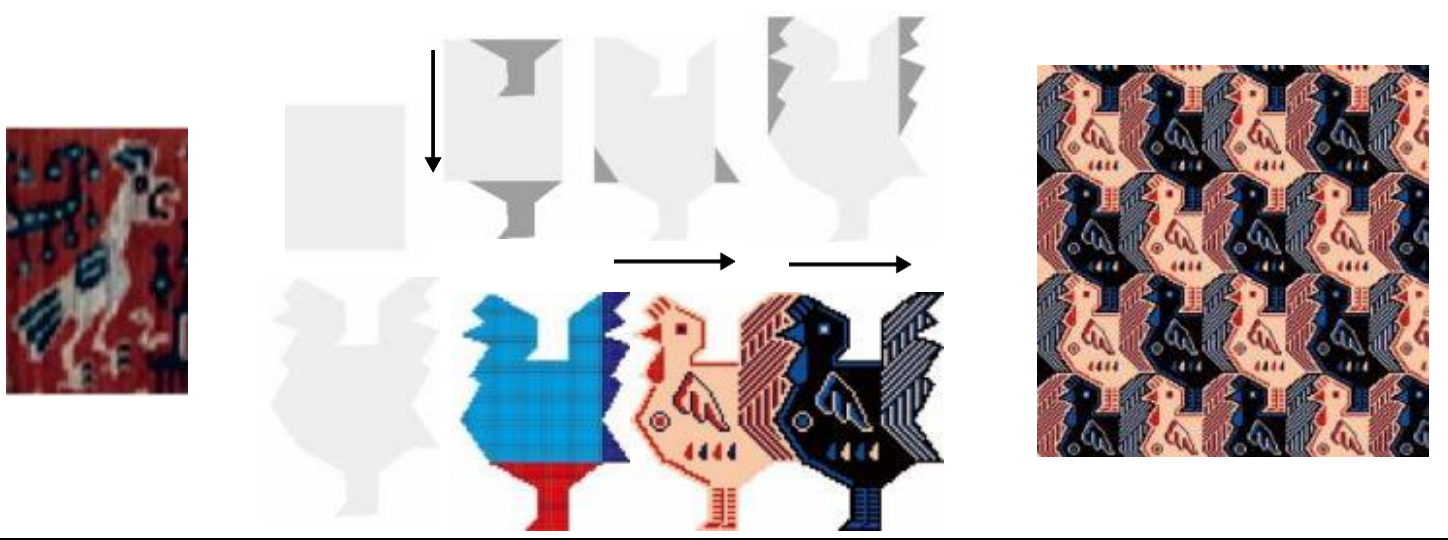

1.

Bentuk geometri dasar dibuat berupa bidang segiempat mengikuti keseluruhan bentuk inspirasi. Sisi atas segiempat dipotong membentuk kepala dan ekor sehingga setelah ditranslasi ke sisi bawah akan membentuk kaki. Sisi kiri segiempat dipotong segitiga untuk membentuk dada lalu ditranslasi ke sisi kanan untuk membentuk ekor. Sisi kiri segiempat dipotong membentuk jengger, paruh, dan dada lalu ditranslasi ke sisi kanan untuk membentuk ekor. Motif dengan siluet ayam jantan yang sudah terbentuk dilakukan percobaan

Keterangan repetisi sebelum diberi warna. Motif kemudian diberi warna dasar mengikuti inspirasi warna tenun ikat Sumba yaitu cream dan hitam, kemudian diberi detail seperti mata, paruh, detail kaki, detail bulu, sayap, jengger juga isen-isen lain yang terinspirasi dari ragam hias tenun ikat hinggi Sumba yang menggunakan prinsip kontras pada warna. Motif dibuat menjadi dua variasi warna yang berbeda, sehingga bentuk motif terlihat jelas setelah dikomposisikan.

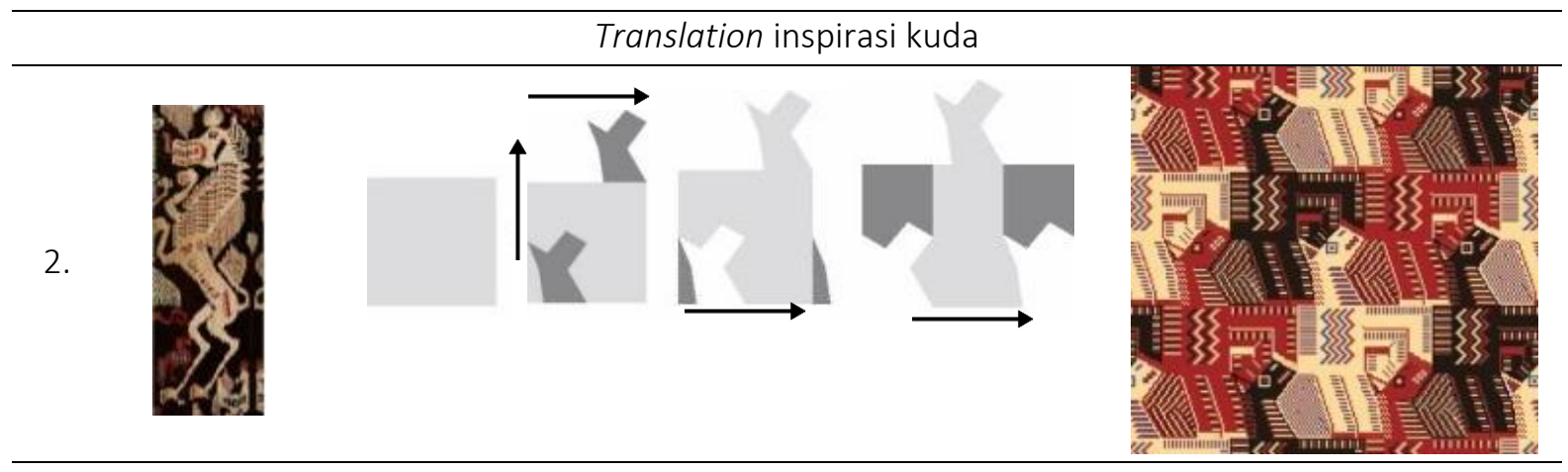




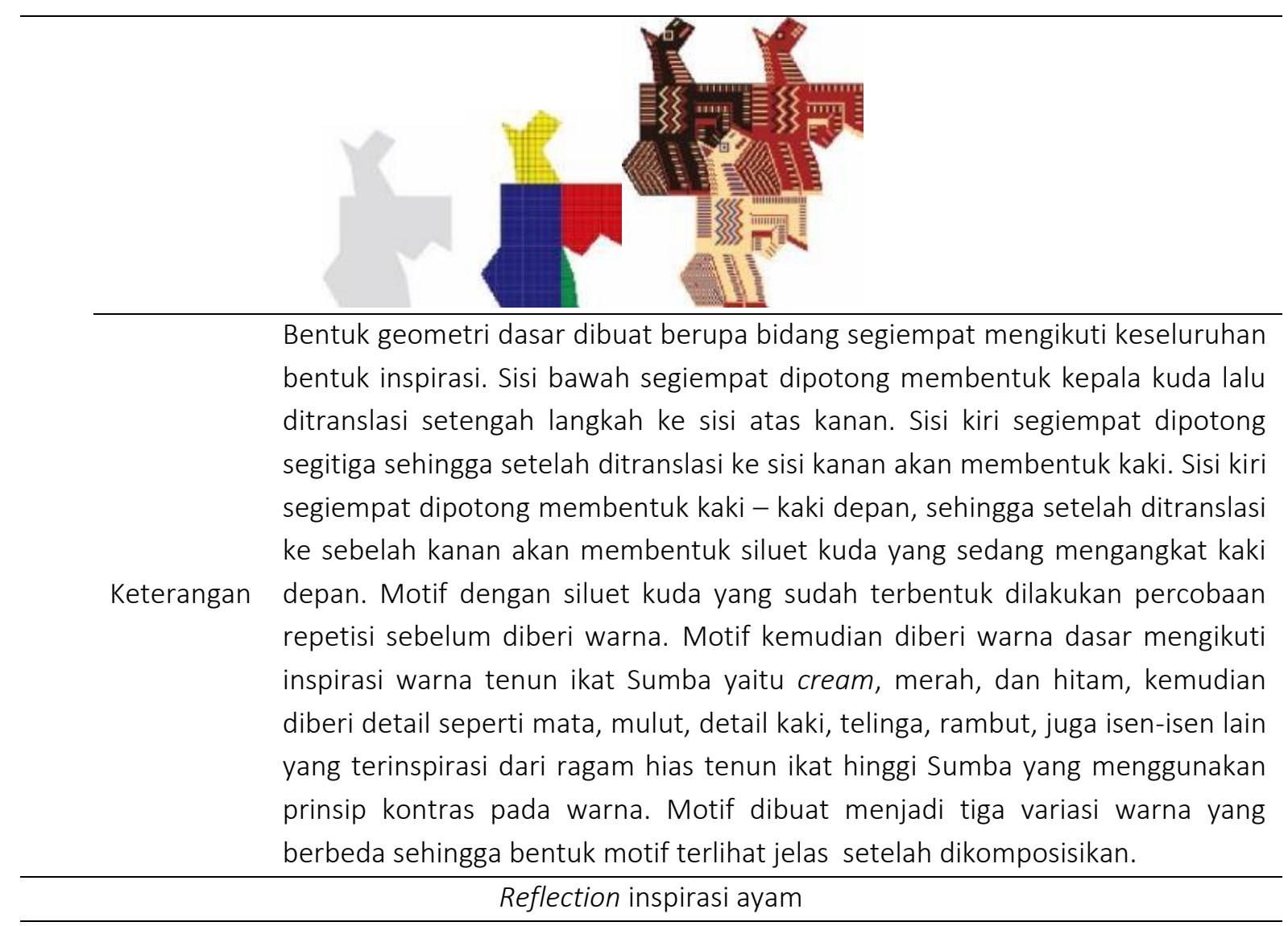

3.
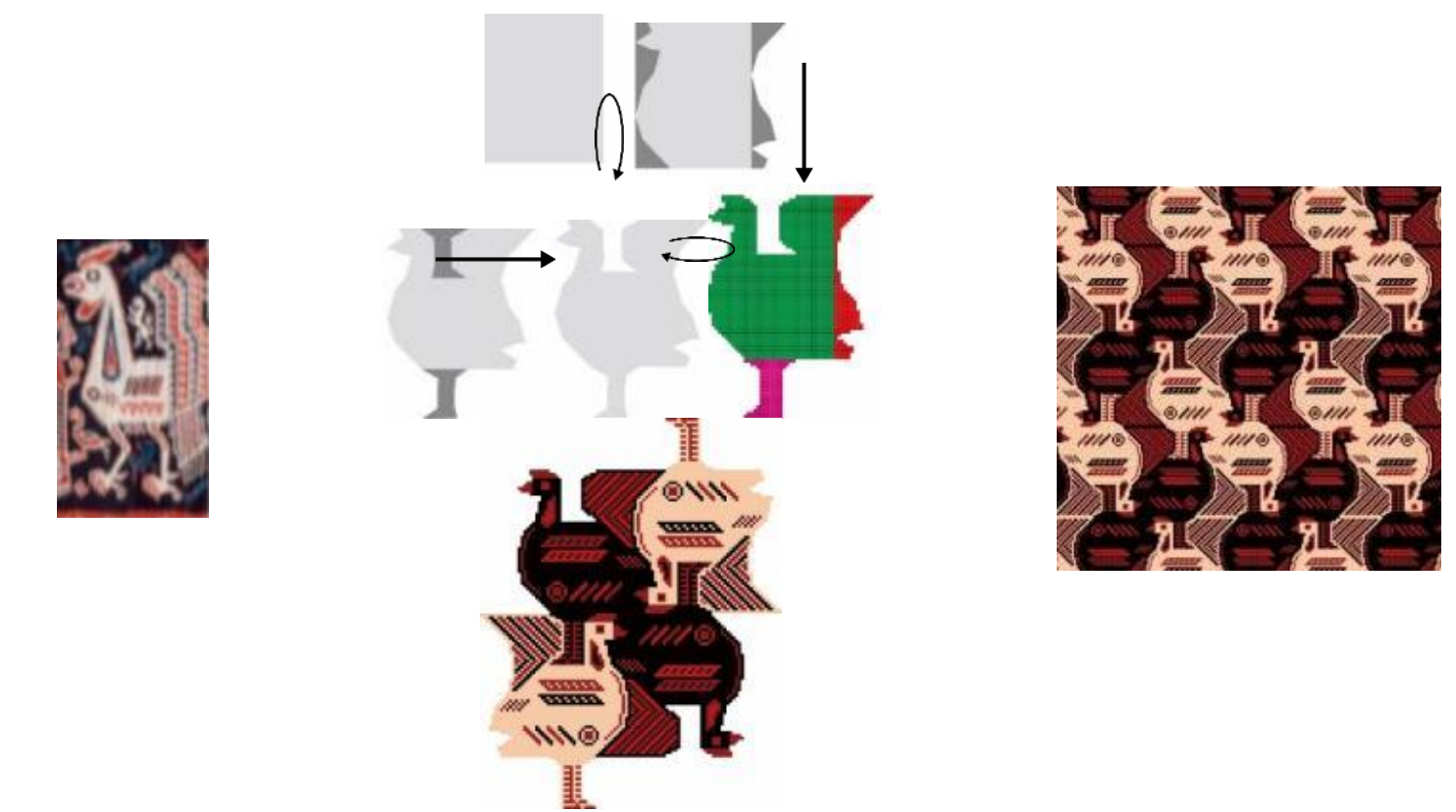

Bentuk geometri dasar dibuat berupa bidang segiempat mengikuti keseluruhan bentuk inspirasi. Sisi kiri segiempat dipotong membentuk jengger, paruh, dan Keterangan dada ayam lalu direfleksi vertikal ke sisi kanan untuk membentuk ekor. Sisi atas segiempat dipotong membentuk kepala dan ekor, sehingga ketika direfleksi horizontal ke sisi bawah terbentuk kaki. Motif dengan siluet ayam jantan yang sudah terbentuk dilakukan percobaan repetisi sebelum diberi warna. Motif 
kemudian diberi warna dasar mengikuti inspirasi warna tenun ikat Sumba yaitu cream dan hitam, kemudian diberi detail seperti mata, paruh, detail kaki, detail bulu, sayap, jengger juga isen-isen lain yang terinspirasi dari ragam hias tenun ikat hinggi Sumba yang menggunakan prinsip kontras pada warna. Motif dibuat menjadi dua variasi warna yang berbeda, sehingga bentuk motif terlihat jelas setelah dikomposisikan.
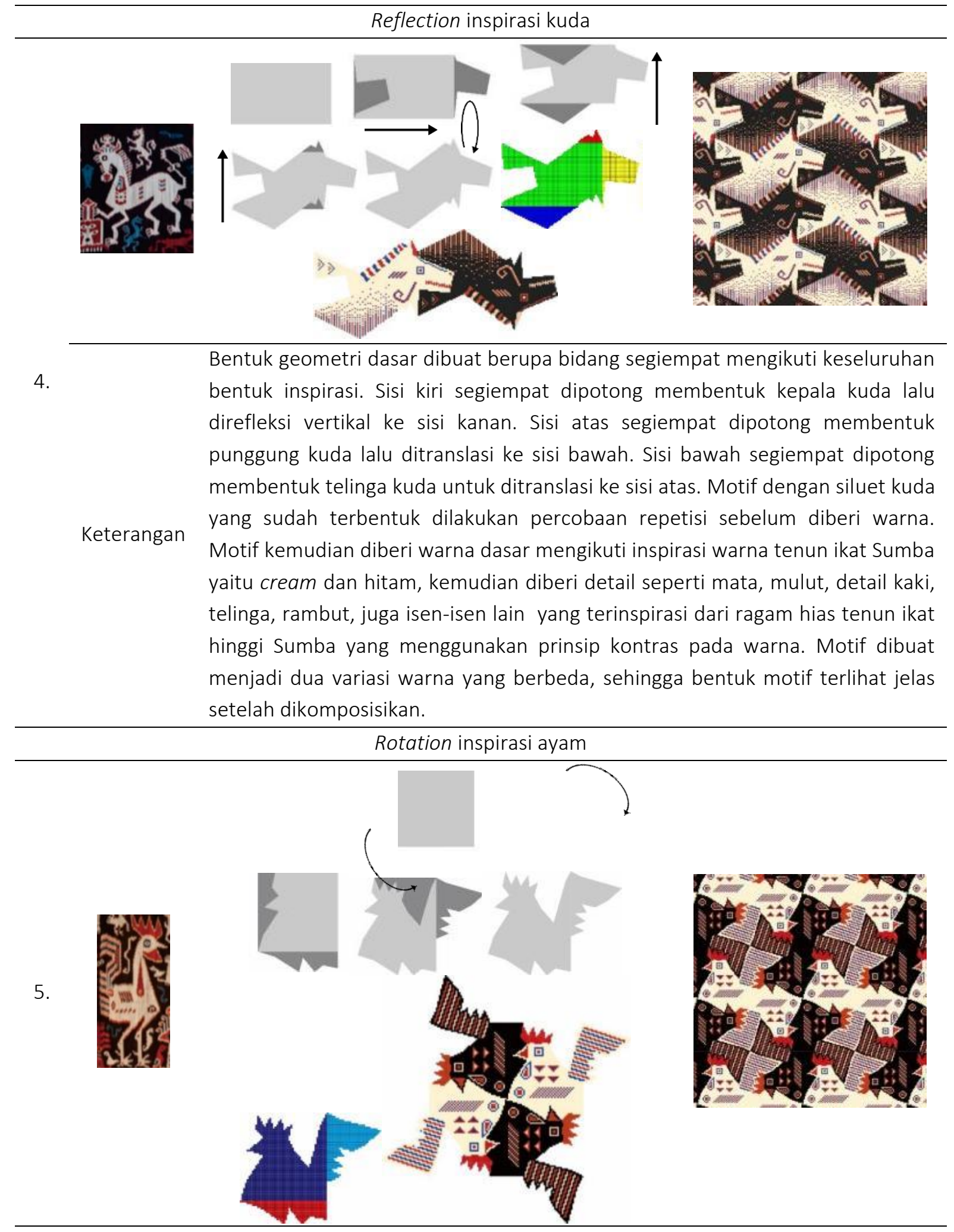
Bentuk geometri dasar dibuat berupa bidang segiempat mengikuti keseluruhan bentuk inspirasi. Sisi kiri segiempat dipotong membentuk jengger, paruh, dan dada ayam lalu dirotasi $90^{\circ}$ ke sisi bawah karena masing-masing sudut segiempat membentuk sudut $90^{\circ}$. Sisi atas segiempat dipotong membentuk jengger dan punggung ayam lalu dirotasi $90^{\circ}$ ke sisi kanan membentuk ekor karena masing-masing sudut segiempat membentuk sudut $90^{\circ}$. Motif dengan

Keterangan siluet ayam jantan yang sudah terbentuk dilakukan percobaan repetisi sebelum diberi warna. Motif kemudian diberi warna dasar mengikuti inspirasi warna tenun ikat Sumba yaitu cream dan hitam, kemudian diberi detail seperti mata, paruh, detail kaki, detail bulu, sayap, jengger juga isen-isen lain yang terinspirasi dari ragam hias tenun ikat hinggi Sumba yang menggunakan prinsip kontras pada warna. Motif dibuat menjadi dua variasi warna yang berbeda, sehingga bentuk motif terlihat jelas setelah dikomposisikan.

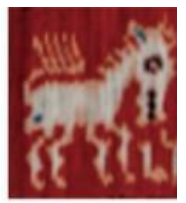

\section{Rotation inspirasi kuda}
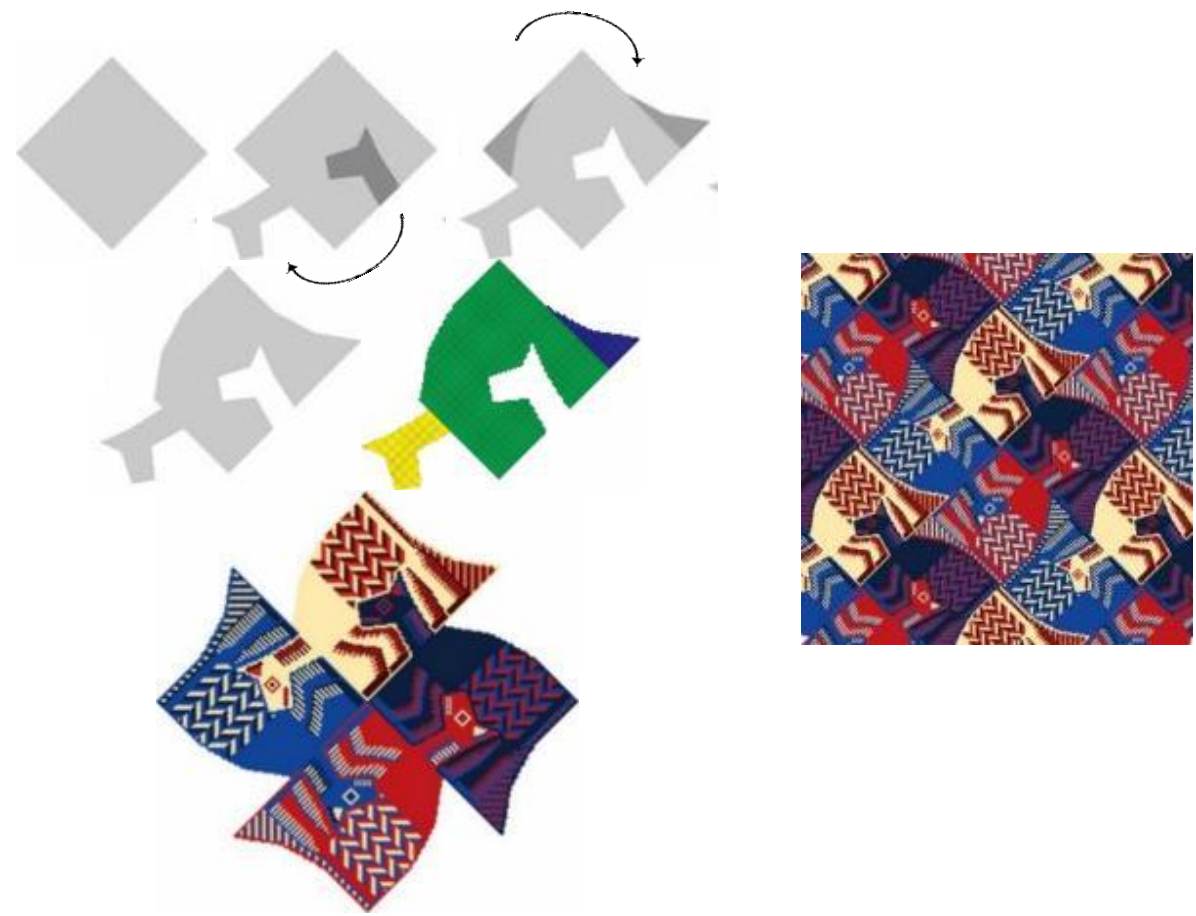

6.

Bentuk geometri dasar dibuat berupa bidang belah ketupat mengikuti keseluruhan bentuk inspirasi. Sisi kanan bawah belah ketupat dipotong membentuk kepala kuda lalu dirotasi $90^{\circ}$ ke sisi kiri bawah karena masing masing sudut belah ketupat membentuk sudut $90^{\circ}$. Sisi kiri atas belah ketupat dipotong membentuk punggung kuda lalu dirotasi $90^{\circ}$ ke sisi kanan atas Keterangan membentuk ekor karena masing-masing sudut belah ketupat membentuk sudut $90^{\circ}$. Motif dengan siluet kuda yang sudah terbentuk dilakukan percobaan repetisi sebelum diberi warna. Motif kemudian diberi warna dasar mengikuti inspirasi warna tenun ikat Sumba yaitu biru, biru tua, cream, dan merah, kemudian diberi detail seperti mata, mulut, detail kaki, telinga, rambut, juga isen-isen lain yang terinspirasi dari ragam hias tenun ikat hinggi Sumba yang menggunakan prinsip kontras pada warna. Motif dibuat menjadi empat variasi 


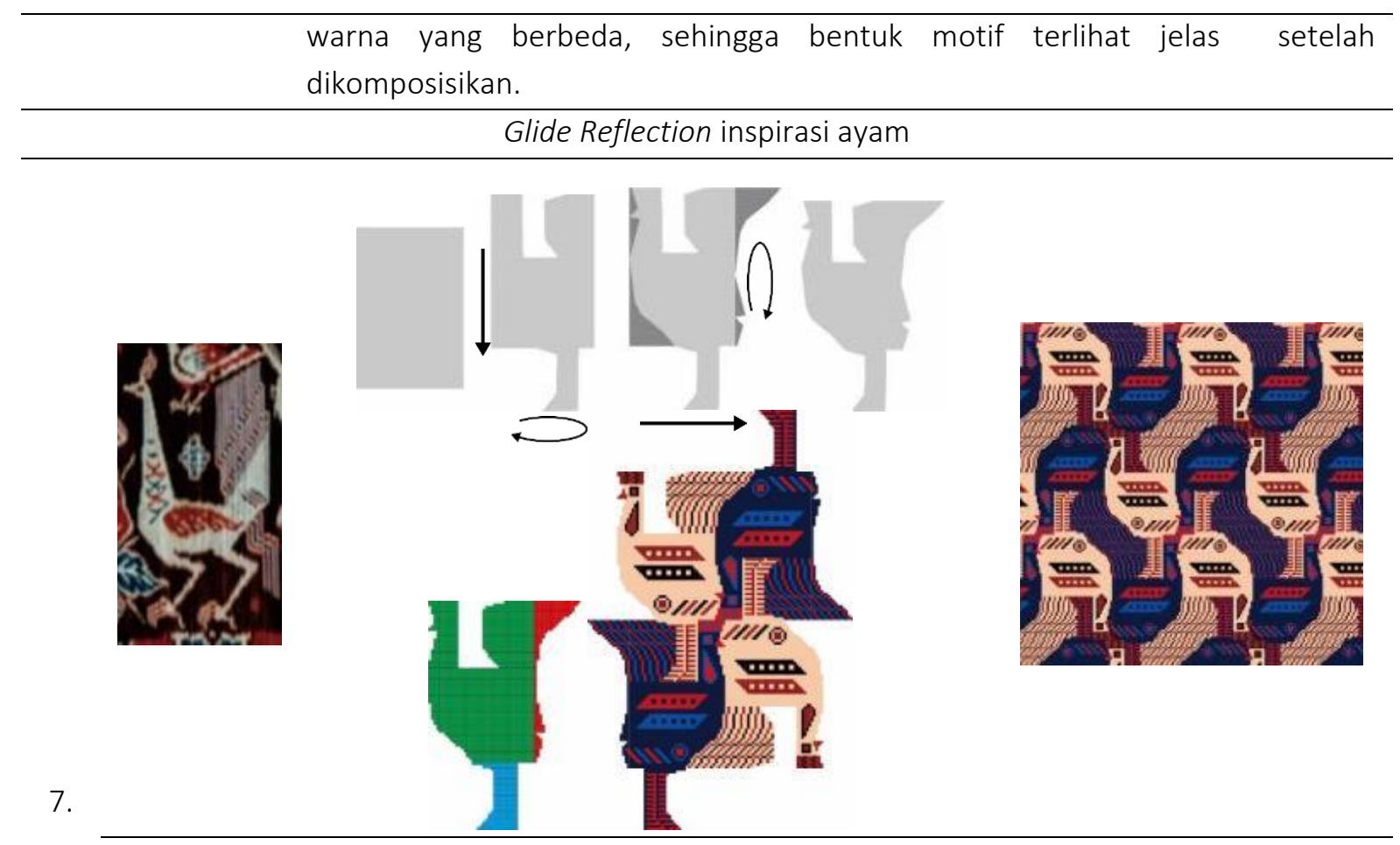

Bentuk geometri dasar dibuat berupa bidang segiempat mengikuti keseluruhan bentuk inspirasi. Sisi atas segiempat dipotong membentuk kepala dan ekor ayam sehingga ketika direfleksi horizontal ke sisi bawah dan ditranslasi ke kanan akan membentuk kaki ayam. Sisi kiri segiempat dipotong membentuk jengger, paruh, dan dada ayam lalu direfleksi vertikal ke sisi kanan membentuk ekor. Motif dengan siluet ayam jantan yang sudah terbentuk dilakukan Keterangan percobaan repetisi sebelum diberi warna. Motif kemudian diberi warna dasar mengikuti inspirasi warna tenun ikat Sumba yaitu cream dan biru tua, kemudian diberi detail seperti mata, paruh, detail kaki, detail bulu, sayap, jengger juga isen-isen lain yang terinspirasi dari ragam hias tenun ikat hinggi Sumba yang menggunakan prinsip kontras pada warna. Motif dibuat menjadi dua variasi warna yang berbeda, sehingga bentuk motif terlihat jelas setelah dikomposisikan.

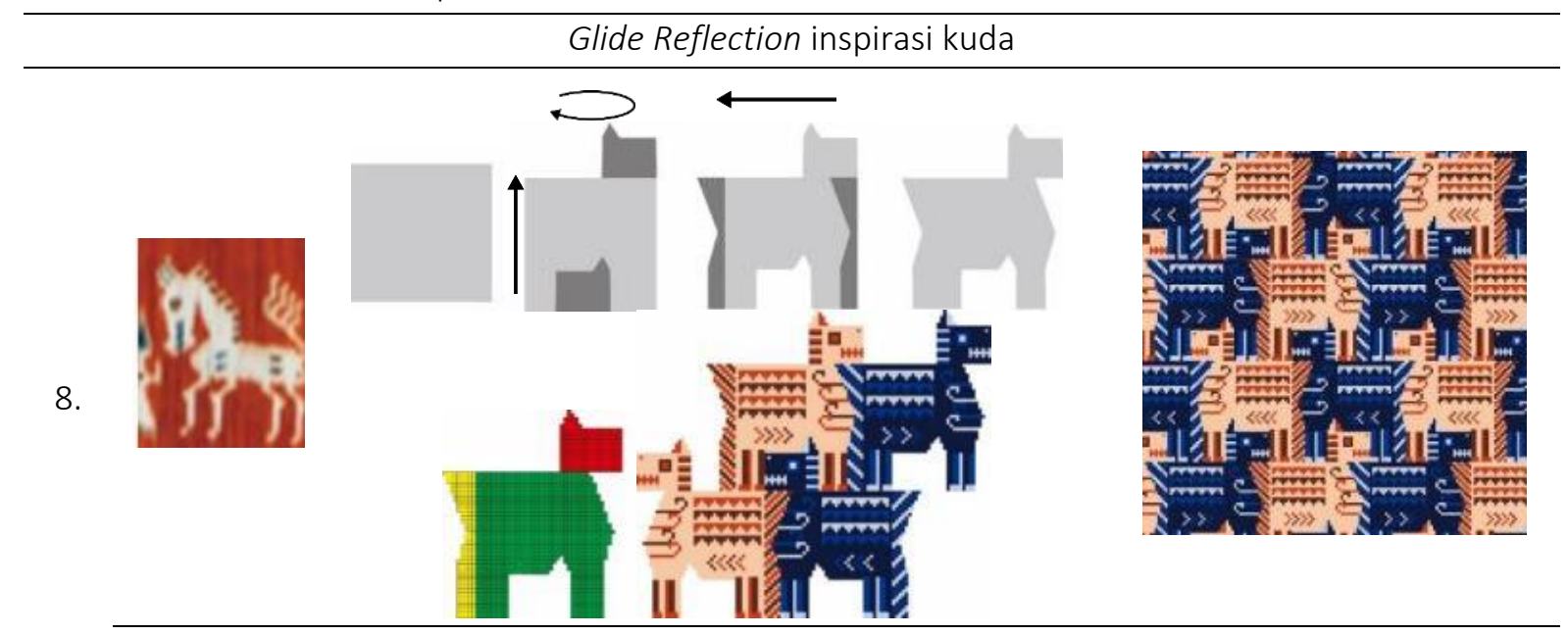

Keterangan

Bentuk geometri dasar dibuat berupa bidang segiempat mengikuti keseluruhan bentuk inspirasi. Sisi bawah segiempat dipotong membentuk kaki kuda, 
sehingga ketika direfleksti horizontal ke sisi atas dan ditranslasi ke kanan akan membentuk kepala kuda. Sisi kanan segiempat dipotong membentuk dada dan kaki depan kuda lalu ditranslasi ke sisi kiri membentuk ekor dan kaki belakang kuda. Motif dengan siluet kuda yang sudah terbentuk dilakukan percobaan repetisi sebelum diberi warna. Motif kemudian diberi warna dasar mengikuti inspirasi warna tenun ikat Sumba yaitu cream dan biru tua, kemudian diberi detail seperti mata, mulut, detail kaki, telinga, rambut, juga isen-isen lain yang terinspirasi dari ragam hias tenun ikat hinggi Sumba yang menggunakan prinsip kontras pada warna. Motif dibuat menjadi dua variasi warna yang berbeda, sehingga bentuk motif terlihat jelas setelah dikomposisikan.

Tabel 2. Ekplorasi Awal II.

(Sumber : Dokumentasi Penulis, 2020)

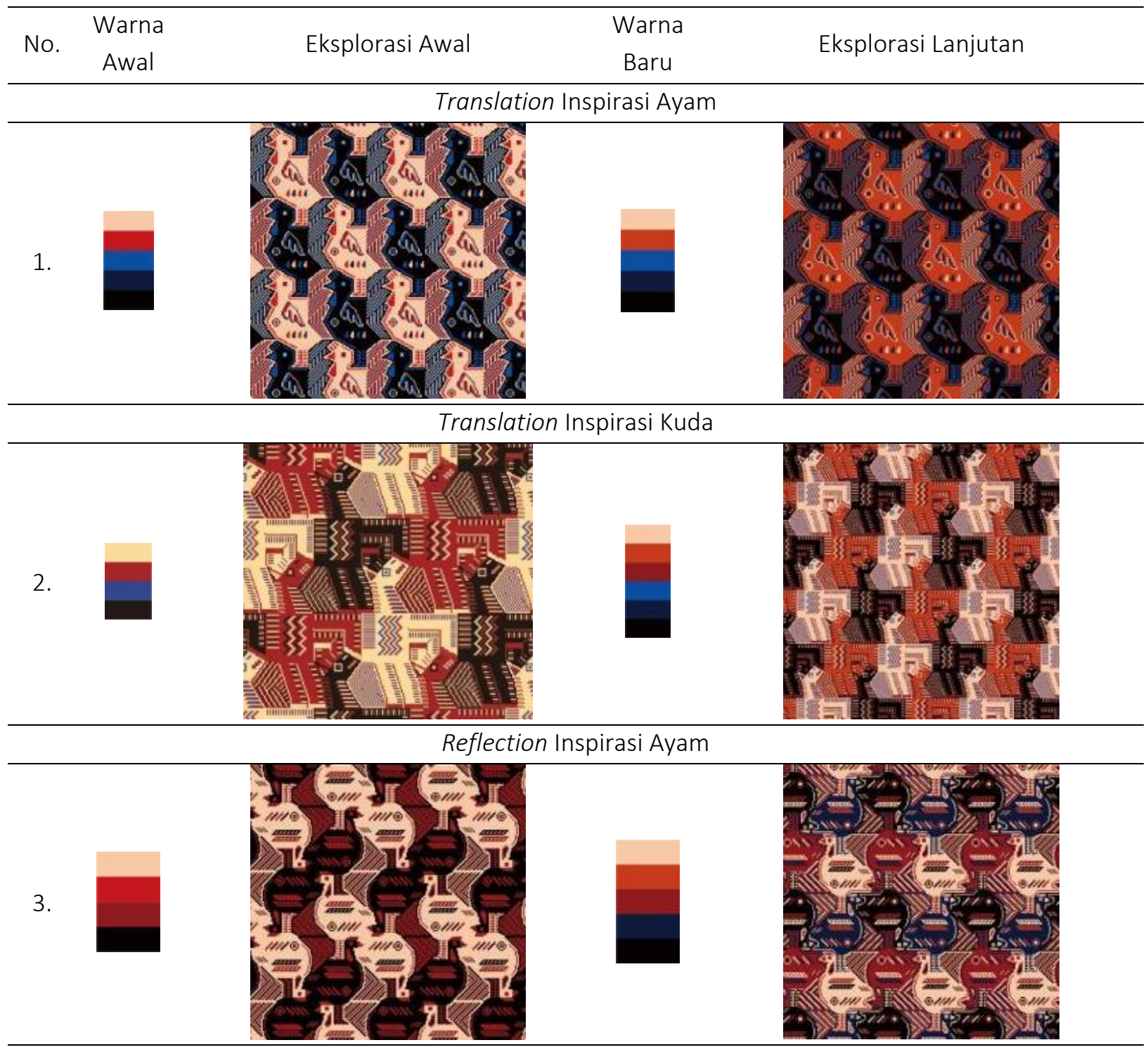

Reflection Inspirasi Kuda 

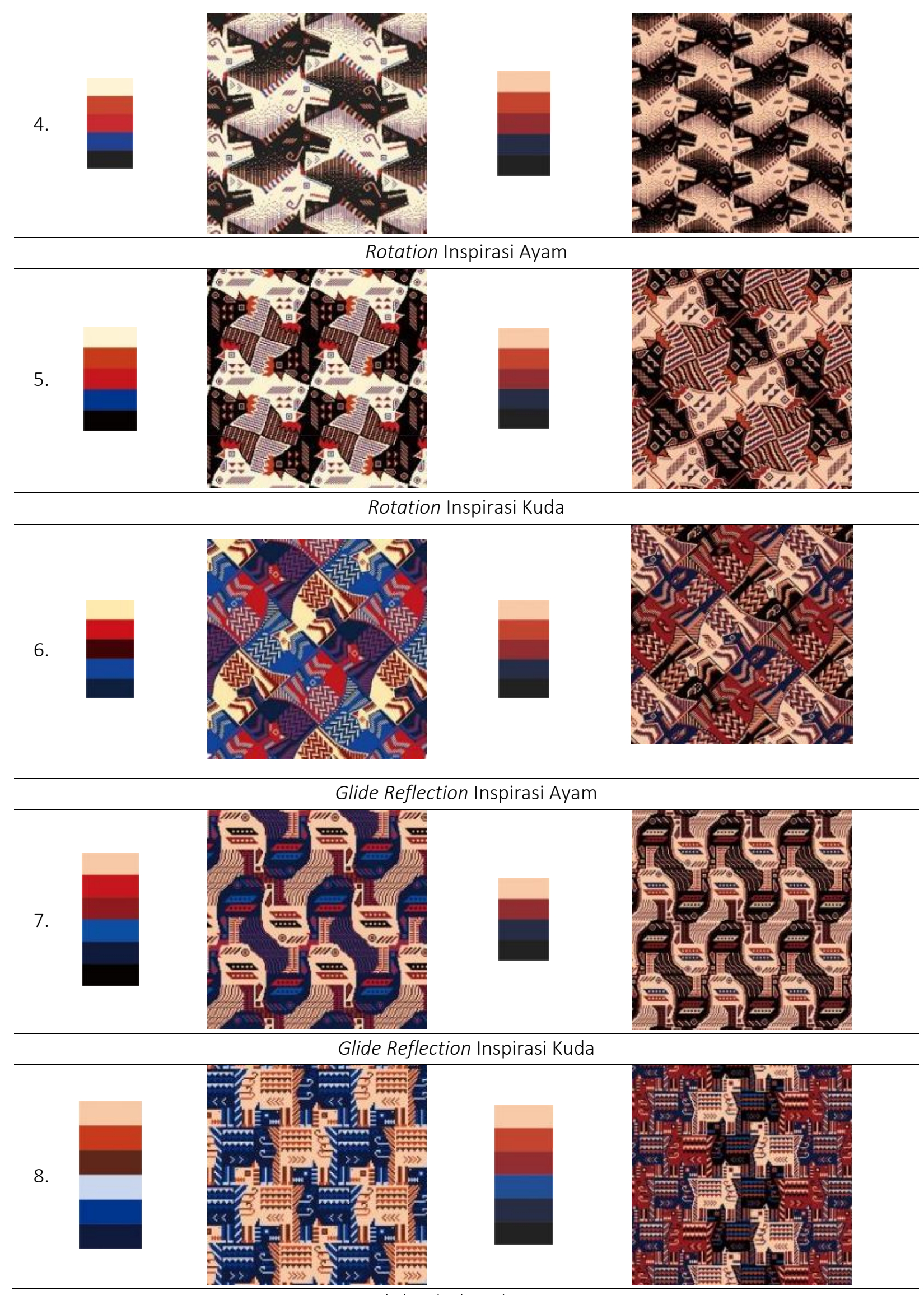

Tabel 3. Eksplorasi lanjutan

(Sumber: Dokumentasi Penulis, 2020) 


\section{f. Produk Akhir}

Sebagai pembuktian pengaplikasian motif pada busana maka dibuat konsep dengan judul IKAT. Ikat diambil dari objek tenun 'ikat' Sumba dimana konsep ini mengangkat budaya tradisional Indonesia yang digabungkan (diikat) bersama perkembangan zaman yang lebih modern. Moodboard konsep dapat dilihat pada gambar 11. Busana berupa pakaian menswear bergaya semi-formal, masculine, dan ethnic. dengan menambahkan unsur busana tradisional Sumba, khususnya motif yang terinspirasi dari ragam hias tenun ikat hinggi Sumba.

Eksplorasi motif diaplikasikan dengan digital printing karena dapat digunakan untuk memproduksi dalam kuantitas kecil, warna yang digunakan beragam, dan bersifat modern. Teknik bordir diaplikasikan pada pattern selain untuk menambah unsur kriya, juga menambah efek tekstur dan memperkuat konsep IKAT dimana pengaplikasian bordir seperti mengikatkan benang pada kain. Produk terdiri dari vest (rompi), jas, dan celana panjang seperti pada gambar 12. Hasil eksplorasi diletakan pada bagian depan jas sebagai pusat perhatian, pada sisi kiri dan kanan celana yang terispirasi dari penggunan tenun ikat hinggi oleh masyarakat Sumba, juga pada bagian sisi kiri dan belakang rompi untuk memberikan keseimbangan dan kesatuan look. Konsep ini dipilih dengan tujuan supaya kebudayaan Indonesia tetap dikenal dan diingat oleh masyarakat Indonesia walaupun zaman terus berkembang hingga saat yang modern ini. Visualisasi produk dapat dilihat pada gambar 13 dan 14.

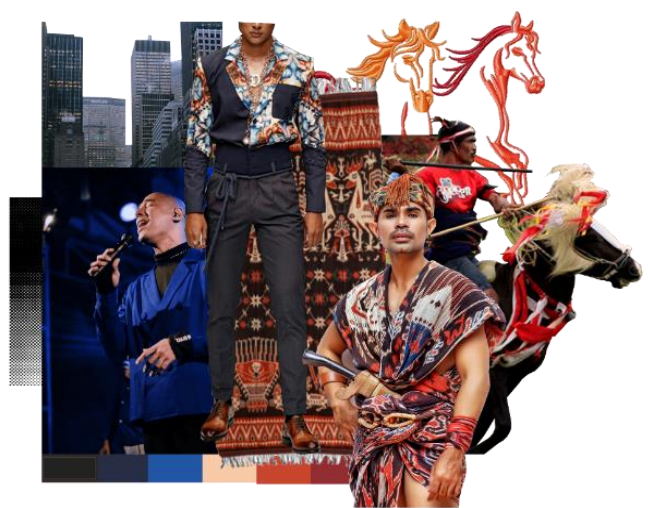

Gambar 11. Moodbpard Konsep IKAT (Sumber: Dokumentasi Penulis, 2020)

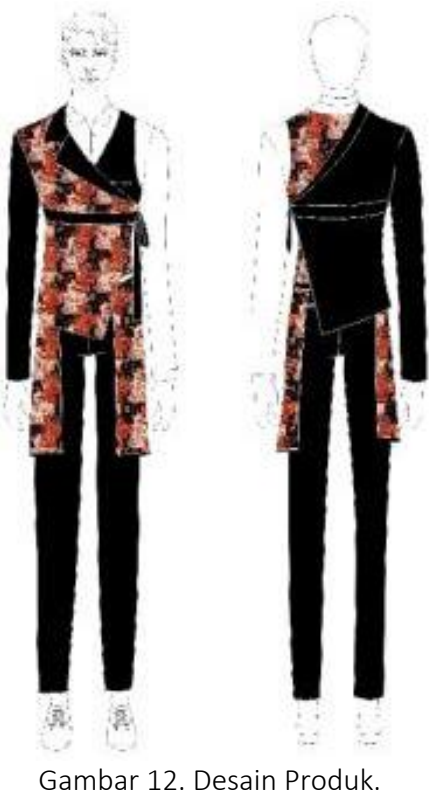

(Sumber: Dokumentasi Penulis, 2020)

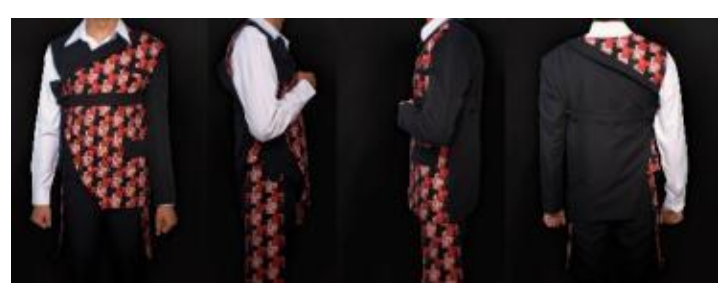

Gambar 13. Visualisasi Produk Lengkap

(Sumber: Dokumentasi Penulis, 2020)

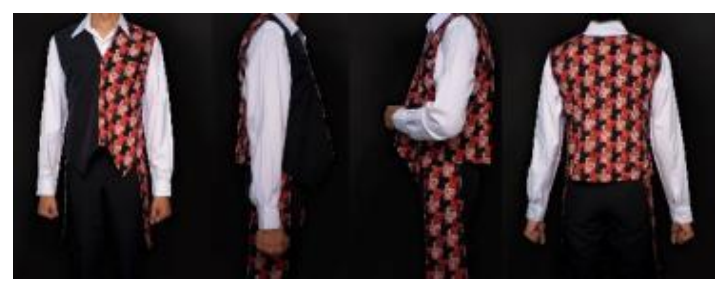

Gambar 14. Visualisasi Produk tanpa Jas (Sumber: Dokumentasi Penulis, 2020) 


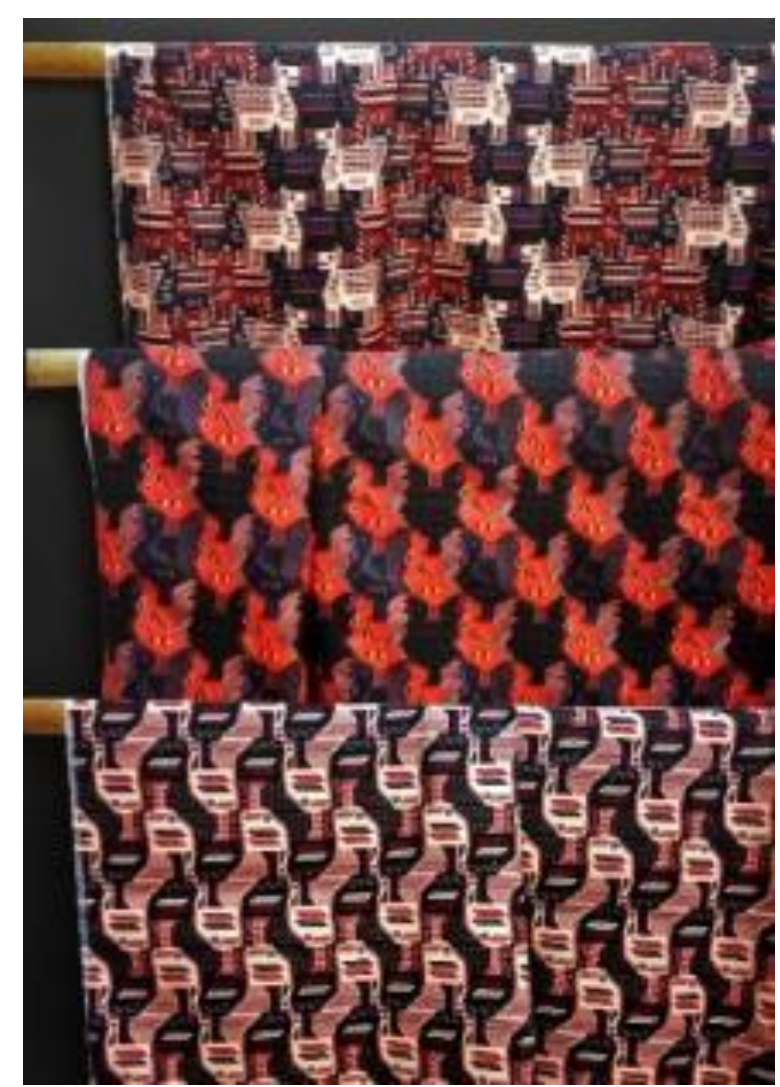

Gambar 15. Visualisasi hasil eksplorasi yang diaplikasikan pada kain menggunakan teknik digital printing dan aksen bordir. (Sumber: Dokumentasi Penulis, 2020)

\section{PENUTUP}

Motif dengan komposisi tessellation pada busana masih bersifat monton, yaitu menggunakan unsur penyusun bidang geometri. Komposisi tessellation dapat disusun dengan unsur penyusun bidang non geometri menggunakan teknik Escher. Inspirasi pengolahan motif menggunakan teknik Escher yaitu, ragam hias tenun ikat hinggi Sumba karena keduanya memiliki kemiripan, khususnya dalam hal unsur penyusun yang berupa bidang non geometri.

Upaya pembuatan variasi motif yaitu, dengan melakukan eksplorasi awal percobaan keempat metode pada teknik Escher menggunakan inspirasi berbagai ragam hias yang ada pada tenun ikat hinggi sumba. Inspirasi ragam hias kemudian dipersempit dengan pertimbangan ragam hias yang sering muncul dalam tenun ikat hinggi Sumba, yaitu ayam jantan dan kuda. Pemilihan ragam hias tersebut sebagai inspirasi juga didasari filosofi ragam hias yang menggambarkan kejantanan dan ketangguhan sesuai dengan target market yang dibuat. Kemudian, dilakukan eksplorasi lanjutan yang menghasilkan eksplorasi yang sesuai dengan konsep dengan judul IKAT yang bergaya semi formal, ethnic dan masculine.

Upaya untuk mengaplikasikan hasil eksplorasi terpilih pada busana yaitu dengan menggunakan teknik digital printing yang merupakan salah satu teknik surface design pada kain dengan pertimbangan kuantitas produksi yang kecil, cepat, warna yang beragam dan harga yang terjangkau. Selain itu, beberapa hasil digital printing diberi tambahan aplikasi teknik bordir dengan tujuan pemberian tekstur yang terinspirasi dari karakter permukaan tenun ikat juga memperkuat konsep yang dibuat. Kain yang dihasilkan diolah menjadi produk busana Ready-to-wear untuk pria yang sudah dibuat berdasarkan konsep.

Pengolahan motif dengan unsur non geometri menggunakan teknik Escher masih dapat dikembangkan dengan menggunakan inspirasi lainnya, baik ragam hias lain yang terdapat pada tenun ikat ikat hinggi Sumba maupun inspirasi yang lainnya. Penggunaan metode rotation pada teknik Escher juga perlu adanya penelitian lebih lanjut karena cenderung lebih sulit dibandingkan dengan ketiga metode lainnya.

\section{DAFTAR PUSTAKA}

Adivi, M. (2019). Spring/Summer 2019 Print Trends. Retrieved November 17 $17^{\text {th }}, 2019$, from https://glowsly.com/spring-summer-2019print-trends/

Deger, O. \& Deger, A. (2012). An Application of Mathematical Tessellation Method In Interior Designing. Procedia - Social and Behavioral Sciences 51, 249-250.

Nizam, A. (2019). Viabilitas Ragam Hias Sulur Gelung Teratai. Jurnal Corak : Jurnal Seni Kriya, 8(2), 134. 
Indonesia Trend Forecasting. (2018). Trend Forecast 2019/2020 : Singularity. Retrieved Retrieved November $17^{\text {th }}, 2019$, from http://trendforecasting.id/singularity

Kartiwa, S. (2007). Tenun Ikat : Ragam Kain Tradisional Indonesia ( $1^{\text {st }}$ ed.). Jakarta : Gramedia Pustaka Utama.

Kusumo, P., Irawani, T., \& Poerwosedjati, D. (2013). Motif Batik Keraton Yogyakarta Sebagai Sumber Inovasi Perhiasan Kotagede. Jurnal Corak: Jurnal Seni Kriya, 2(1), 14.

Rosandini, M \& Kireina, Y. (2020). Kajian Bahasa Rupa Pada Batik Gendongan Lasem Motif Pohon Hayat dan Satwa. Jurnal Gelar : Jurnal Seni Budaya, 18(1), 18.

Soeriadiredja, P. (2013). Dinamika Kain Tenun Tradisional Sumba. Museum Tekstil Jakarta. $1-2$.

Taschen. (2009). M. C. Escher: The Graphic Work. New York: Barnes \& Noble, Inc. 